\title{
Enthalpy of Dissolution and Dehydration of Two Moroccan Clays
}

\author{
Jabrane Maissara1, Halima Karym¹, Mohammed El Mahi Chbihi', Mohammed Moutaabbid1, \\ Mohamed Abatal'2, Said Benmokhtar ${ }^{*}$
}

\author{
${ }^{1}$ Department of Chemistry, Faculty of Sciences, Laboratory of Chemistry and Physics of Materials LCPM, Faculty of Sciences Ben \\ M'Sik, University of Casablanca, Casablanca, Morocco \\ ${ }^{2}$ Laboratory of Investigation of Advanced Materials, Faculty of Engineering in Autonomous University, El Carmen, Mexico \\ Email: *sbenmokhtar@yahoo.com
}

How to cite this paper: Maissara, J., Karym, H., El Mahi Chbihi, M., Moutaabbid, M., Abatal, M. and Benmokhtar, S. (2018) Enthalpy of Dissolution and Dehydration of Two Moroccan Clays. World Journal of Engineering and Technology, 6, 119-127.

https://doi.org/10.4236/wjet.2018.61007

Received: December 7, 2017

Accepted: February 4, 2018

Published: February 7, 2018

Copyright $\odot 2018$ by authors and Scientific Research Publishing Inc. This work is licensed under the Creative Commons Attribution International License (CC BY 4.0).

http://creativecommons.org/licenses/by/4.0/

\begin{abstract}
This work aims to characterize and determine the dehydroxylation enthalpy variations of two natural Moroccan clays from the Nador region (denoted K1) and the Settat region (denoted by K2). The variations of dissolution enthalpies were determined by dissolving clays in hydrofluoric acid. They have a minimum value for dehydroxylation of clays made between $600^{\circ} \mathrm{C}$ and $700^{\circ} \mathrm{C}$. The analysis of the two clays shows that they consist of kaolinite in significant proportion. The optimum calcination parameters, for which dehydroxylation is total, are $700^{\circ} \mathrm{C}$ with a heating time of $6 \mathrm{H}$. The conversion of the kaolinite to metakaolinite was confirmed by IR analyses of the starting and thermally treated kaolin samples. The result confirms previous observations about obtaining metakaolinite with optimum reactivity when hydrated with calcium hydroxide as chemical activator.
\end{abstract}

\section{Keywords}

Clay, Characterization, Dissolution, Calorimetry, IR

\section{Introduction}

Development of construction materials which offers technical and environmental benefits is the main challenge of the new millennium. One of such materials is metakaolin (MK), pozzolanic addition, which is classified as a new generation of supplementary cementitious material. Supplementary cementitious materials (SCMs) are finely ground solid materials that are used to replace part of the clinker in a cement or cement in a concrete mixture. Use of metakaolin in cement-based systems, provides, beside technical [1] [2], significant environmental benefits [3]. 
Metakaolin is unique in that it is not the by-product of an industrial process, nor is it entirely natural; it is derived from a naturally occurring mineral, and is manufactured specifically for cementing applications. Metakaolin is usually produced by thermal treatment, i.e., calcination of kaolin clays within a definite temperature range. Metakaolin, pozzolanic additive, may be obtained by calcination of kaolin clay. The optimal conditions of the thermal treatment are: calcination temperature of $650^{\circ} \mathrm{C}$ and heating time of $90 \mathrm{~min}[4]$.

During a thermal treatment in air, the clay minerals are the subject of a number of successive structural transformations involving the dehydroxylation of the solid, then the formation of phases which are being called high-temperature phases [5]. Some clays lead by dehydroxylation at intermediate or transitional phases with very marked state of disorganization of the crystal lattice. This phenomenon concerns in particular the kaolinite and halloysite, antigorite and chrysotile, the montmorillonite, talc, chlorites and some vermiculite [6].

These phases of crystallographically disorganized structure generally have a high chemical reactivity and in particular they exhibit a certain pozzolanic pouvoir (consolidation and curing after mixing with water and the calcium hydroxide acting as a chemical activator).

The semi-quantitative analysis of the state of disorganization of the crystalline lattice, therefore of the reactivity, the intermediate phases and the natural and artificial pozzolans can make use of numerous experimental techniques including X-ray diffraction [7], IR [8], or other reactivity tests such as monitoring fixation kinetics of calcium hydroxide in an aqueous medium [9], conductimetry [10] or calorimetry [11].

The latter method [12] has been used to determine pozzolanic activity of different solids, including the metakaolinite, by studying the evolution of dissolution heat when dissolved in a mixture of hydrofluoric acid and nitric acid and determining the insoluble residue.

Finally, our results are in perfect agreement with those found in a previous article by Karym et al. [13].

We have used this calorimetric method to try to characterize the amorphization state of the metakaolinite by measuring the enthalpy of dissolution in hydrofluoric acid and thus the correlate data and pozzolanic activity shown of solid according to its temperature dehydroxylation.

In this work, the influence of thermal treatment on the structure of two natural Moroccan clays from the Nador region (denoted K1) and the Settat region (denoted by K2) was studied, using infrared spectroscopy and dissolution calorimetry.

The aim of our work is to try to characterize and compare the amorphization state of the two metakaolinites by measuring their dissolution enthalpies in hydrofluoric acid and to deduce the enthalpies of dehydration and thus establish the correlation between these data and the pozzolanic activity exhibited by the solid as a function of its preparation temperature by dehydroxylation of kaolin. 


\section{Experimental}

\subsection{Solution Calorimeter}

The Parr 1455 Solution Calorimeter is used for to measure the heat evolved or absorbed by chemical reactions in a liquid media. Measurements were made at room temperature $\left(20^{\circ} \mathrm{C}\right)$ and atmospheric pressure. At the start of a test in this calorimeter, one liquid is held in a glass Dewar while, the other reactant, solid, is held in a Teflon rotating cell sealed which is immersed in the first liquid. After both reactants come to thermal equilibrium, the operator starts the reaction by depressing a push rod to drop the contents of the cell into the surrounding liquid. The reaction then proceeds to completion under the vigorous stirring action of the rotating cell. Throughout the test, temperatures in the calorimeter are sensed by a thermistor and read from a microprocessor based thermometer which is built into the calorimeter case. Digital readings are shown on an LED display and fed to outputs for printer or computer. There is also an analog output for a strip chart recorder to produce a thermogram showing the temperature change produced by the reaction. Data from the thermogram or computer memory can then be used to compute the change in enthalpy.

The calorimetric technique that we used is clear that if the dissolution is fast enough. Otherwise, the end of the post reaction period is very difficult to determine, and it is virtually impossible to measure the thermal effect correctly (uncertainty can exceed $10 \%$ of the value found). That is why several dissolution tests were initially carried out in different medium to determine the optimum conditions. The nature of the studied aluminosilicate prompted us to choose solutions containing hydrofluoric acid. Following these tests, the solutions were performed in hydrofluoric acid $14.4 \mathrm{~mol} \cdot \mathrm{l}^{-1}$ obtained by diluting commercial acid (Carlo Erba) to $48 \%$ by weight of half.

The two clays used in this work are noted K1 (region of Nador Morocco) and K2 (region of Settat Morocco). The enthalpies of dissolution for the two clays are measured under the same conditions.

\subsection{Infrared Spectrometry}

Spectra were recorded in the range $4000-400 \mathrm{~cm}^{-1}$ with a Perkin-Elmer IR 983G spectrophotometer, using samples dispersed in spectroscopically pure KBr pellets.

\subsection{Fluorescence $X$}

The basic chemical analysis of the materials used was carried out with an XRF Bruker S8 Tiger device. According to Table 1, the results indicate that the predo-

Table 1. X-ray fluorescence analysis.

\begin{tabular}{cccccccccccc}
\hline & $\mathrm{H}_{2} \mathrm{O}$ & $\mathrm{SiO}_{2}$ & $\mathrm{Al}_{2} \mathrm{O}_{3}$ & $\mathrm{Fe}_{2} \mathrm{O}_{3}$ & $\mathrm{CaO}$ & $\mathrm{MgO}$ & $\mathrm{SO}_{3}$ & $\mathrm{~K}_{2} \mathrm{O}$ & $\mathrm{Na}_{2} \mathrm{O}$ & $\mathrm{P}_{2} \mathrm{O}_{5}$ & $\mathrm{TiO}_{2}$ \\
\hline $\mathrm{K} 1$ & 12.4 & 47.07 & 36.49 & 0.97 & 0.29 & 0.46 & 0.15 & 2.067 & 0.184 & 0.123 & 0.114 \\
$\mathrm{~K} 2$ & 13.61 & 42.62 & 35.32 & 4.34 & 1.49 & 0.17 & 0.26 & 0.08 & 0.02 & 0.57 & 0.64 \\
\% theor & 13.95 & 46.51 & 39.53 & - & - & - & - & - & - & - & - \\
\hline
\end{tabular}


minant constituents are Silica and Alumina, this indicates the presence of Kaolinite $\left(\mathrm{Al}_{2} \mathrm{Si}_{2} \mathrm{O}_{5}(\mathrm{OH})_{4}\right)$.

\section{Results and Discussions}

\subsection{Enthalpy of Dissolution}

First of all, from a qualitative point of view, for each clay, the variation of the dissolution enthalpy as a function of the treatment temperature is predictable: the dissolution of a crystalline anhydrous compound is always more exothermic than that of the hydrate corresponding. The first part of each curve (temperature below $700^{\circ} \mathrm{C}$ ) corresponds to this case. The decrease in the exothermicity of the dissolution corresponds to a start of recrystallization of the product for temperatures above $700^{\circ} \mathrm{C}$. In addition, significant differences are obtained for the starting kaolinites, the dissolution being all the more exothermic as the product is less organized.

The values of the dissolution enthalpies of the clays treated at different temperatures (denoted MK1 and MK2) are reported in Table 2. Figure 1 represents the variation of the enthalpy of dissolution as a function of the calcination temperature. The maximum of the curve does not correspond to the same temperature for the two clays (K1 and $\mathrm{K} 2$ ). K2 very disorganized, leads rapidly to a weak

Table 2. Variation of enthalpy of dissolution in HF of the two kaolinites (J.g $\left.{ }^{-1}\right)$.

\begin{tabular}{cccccccc}
\hline Temp ( $\left.{ }^{\circ} \mathrm{C}\right)$ & 400 & 500 & 600 & 700 & 800 & 900 \\
\hline$-\Delta_{\text {diss }} H_{M K 1}^{0}\left(\mathrm{~J} \cdot \mathrm{g}^{-1}\right)$ & 2242.16 & 2570.81 & 2924.76 & 2977.6 & 2953.45 & 2691.3 \\
$-\Delta_{\text {diss }} H_{\text {MK } 2}^{0}\left(\mathrm{~J} \cdot \mathrm{g}^{-1}\right)$ & 2338.96 & 2747.65 & 3124.88 & 2326.86 & 1194.36 & 871.12 \\
\hline & & & & & & & \\
\hline
\end{tabular}

Figure 1. Enthalpy of dissolution in hydrofluoric acid depending on the treatment temperature. 
maximum, the dissolution enthalpy of $\mathrm{K} 1$ varies very little for samples prepared between $500^{\circ} \mathrm{C}$ and $900^{\circ} \mathrm{C}$. The gap between the maximum dissolution enthalpy of metakaolin (MK1 and MK2) and that of kaolin (K1 and K2) also seems to vary as the degrees of crystallinity of the starting material, which confirms the collapse of the network at its dehydroxylation.

Note that we performed several tests and we observed that the uncertainty on the results obtained does not exceed $1.5 \%$.

\subsection{Enthalpy of Dehydration}

Since the clays studied consist of major kaolinites in addition to other constituents such as $\mathrm{Fe}_{2} \mathrm{O}_{3}, \mathrm{CaO}, \mathrm{MgO}, \mathrm{Na}_{2} \mathrm{O}$ and $\mathrm{K}_{2} \mathrm{O}$, the formula of the raw kaolinite starting can be expressed by: $\mathrm{Al}_{2} \mathrm{O}_{3}, 2 \mathrm{SiO}_{2}, 2 \mathrm{H}_{2} \mathrm{O}+\mathrm{I}$. I being all the other constituents.

The dissolution reaction of kaolinite $(\mathrm{K})$ in hydrofluoric acid is:

$$
\mathrm{Al}_{2} \mathrm{O}_{3}, 2 \mathrm{SiO}_{2}, 2 \mathrm{H}_{2} \mathrm{O}(\mathrm{s})+24 \mathrm{HF}(\mathrm{aq}) \rightarrow 2 \mathrm{H}_{2} \mathrm{SiF}_{6}(\mathrm{aq})+2 \mathrm{H}_{3} \mathrm{AlF}_{6}(\mathrm{aq})+9 \mathrm{H}_{2} \mathrm{O}(\mathrm{aq})
$$

Assuming anhydrous metakaolin for firing temperatures in the region of $700^{\circ} \mathrm{C}$, the dissolution reaction of metakaolin $(\mathrm{MK})$ in hydrofluoric acid is:

$$
\mathrm{Al}_{2} \mathrm{O}_{3}, 2 \mathrm{SiO}_{2}+24 \mathrm{HF}(\mathrm{aq}) \rightarrow 2 \mathrm{H}_{2} \mathrm{SiF}_{6}(\mathrm{aq})+2 \mathrm{H}_{3} \mathrm{AlF}_{6}(\mathrm{aq})+7 \mathrm{H}_{2} \mathrm{O}(\mathrm{aq})
$$

The variation of the dehydration enthalpy is calculated by first assuming the pure products. Indeed:

$$
\Delta H_{\text {dehydr }}^{0}(\mathrm{~K})=\Delta H_{f}^{0}(\mathrm{MK})-\Delta H_{f}^{0}(\mathrm{~K})+2 \Delta H_{f}^{0}\left(\mathrm{H}_{2} \mathrm{O}\right)(\mathrm{g})
$$

likewise that,

$$
\Delta H_{\text {diss }}^{0}(\mathrm{~K})-\Delta H_{\text {diss }}^{0}(\mathrm{MK})=2 \Delta H_{f}^{0}\left(\mathrm{H}_{2} \mathrm{O}\right)(\mathrm{aq})-\Delta H_{f}^{0}(\mathrm{~K})+\Delta H_{f}^{0}(\mathrm{MK})
$$

Note that in the expression $\Delta H_{\text {diss }}^{0}(\mathrm{~K})-\Delta H_{\text {diss }}^{0}(\mathrm{MK})$, the thermal effect due to I (all other constituents) vanishes from where:

$$
\Delta H_{\text {dehydr }}^{0}(\mathrm{~K})=2 \Delta H_{\text {vap }}^{0}\left(\mathrm{H}_{2} \mathrm{O}\right)+\Delta H_{\text {diss }}^{0}(\mathrm{~K})-\Delta H_{\text {diss }}^{0}(\mathrm{MK})
$$

Table 3 gives the values of the dehydration enthalpy variation of the two kaolinites studied. The starting materials being impure, these values are expressed in $\mathrm{J} \cdot \mathrm{g}^{-1}$.

These heats of dehydration can only be given as an indication. In reality the impurities of kaolinite modify the real value. During dehydration there is disruption of the network whose thermal effect is also measured. In addition, if the metakaolinite is heated to higher temperatures, recrystallization occurs (recrystallization noted by decreasing the exothermic effect of the dissolution). That is why we used the anhydrous reference state as the baking temperature, which

Table 3. Variation of enthalpy of dehydration of the two kaolinites.

\begin{tabular}{cccc}
\hline Clay & $-\Delta_{\text {diss }} H_{K}^{0}\left(\mathrm{~J} \cdot \mathrm{g}^{-1}\right)$ & $-\Delta_{\text {dis }} H_{\text {MK }}^{0}\left(\mathrm{~J} \cdot \mathrm{g}^{-1}\right)$ & $\Delta_{\text {den }} H^{0}\left(\mathrm{~J} \cdot \mathrm{g}^{-1}\right)$ \\
\hline $\mathrm{K} 1$ & 2029.52 & $2977.60\left(700^{\circ} \mathrm{C}\right)$ & 873.68 \\
$\mathrm{~K} 2$ & 2251.36 & $3124.88\left(600^{\circ} \mathrm{C}\right)$ & 778.57 \\
\hline
\end{tabular}


corresponds to a maximum heat of dissolution.

\subsection{Infrared Spectroscopy}

IR Besides XRD measurements, IR spectroscopy was applied to confirm kaolinite transformation during calcinations. IR spectra obtained for starting clay and thermally treated samples are presented in Figure 2. The results of IR spectroscopy of starting clay (Figure 2(a) \& Figure 2(c)) show the characteristic bands of kaolinite [14]: $\mathrm{OH}^{-}$at 3695, 3668, 3651 and $3620 \mathrm{~cm}^{-1}$; Al-OH at $914 \mathrm{~cm}^{-1}$; $\mathrm{Si}-\mathrm{O}$ at $1020,1105,465 \mathrm{~cm}^{-1}$ and $\mathrm{Si}-\mathrm{O}-\mathrm{Al}^{\mathrm{VI}}$ at $540 \mathrm{~cm}^{-1}$. Absence of the detectable Al-O-H bands at $914 \mathrm{~cm}^{-1}$, and the doublet at 3707 and $3622 \mathrm{~cm}^{-1}$, is evident from Figure 2(b) \& Figure 2(d).
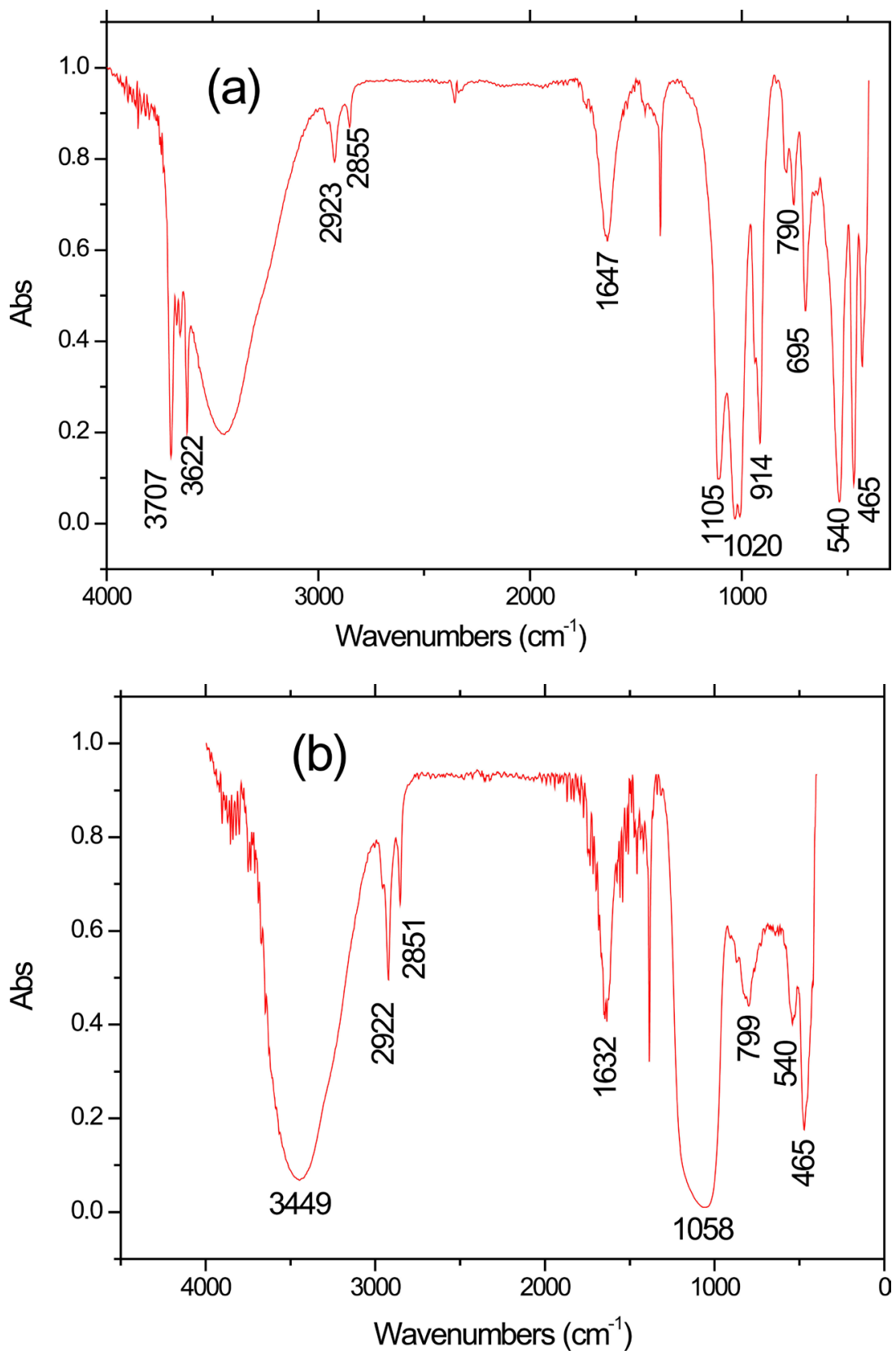

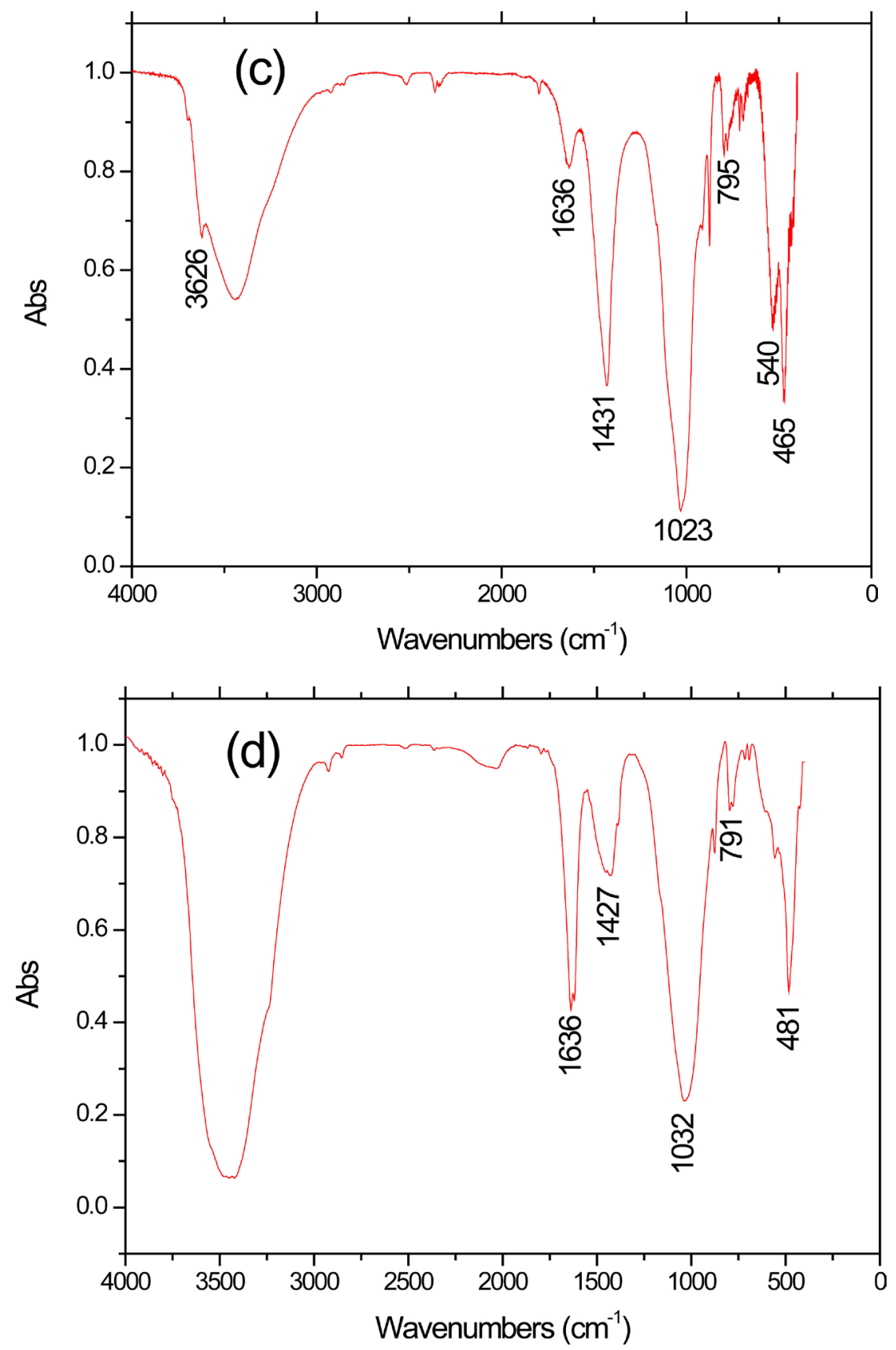

Figure 2. Starting K1 (a) and thermally treated at $700^{\circ} \mathrm{C}$ (b), Starting $\mathrm{K} 2$ (c) and treated at $700^{\circ} \mathrm{C}(\mathrm{d})$.

Figure 2(c) shows the absence of the bands at 3695,3668 and $3651 \mathrm{~cm}^{-1}$ for the starting clay (K2), which suggests that the compound $\mathrm{K} 2$ is more disorganized than K1. This result is in perfect agreement with the enthalpies of dehydration calculated in the preceding paragraph.

\section{Conclusion}

In this work, we studied by calorimetry the dissolution in hydrofluoric acid of two kaolinites and metakaolinites. The variation of the dissolution enthalpies as 
a function of the thermal activation conditions $(6 \mathrm{~h})$ made it possible to specify in each case the optimum temperature for obtaining a solid in the state of maximum crystalline disorganization. A beginning of crystallization of the metakaolinite is always demonstrated by a decrease in the exothermicity of the reaction as soon as the calcination temperature reaches a temperature of about $800^{\circ} \mathrm{C}$.

The infrared spectra recorded for the two kaolinites confirm that kaolinite K2 is more disorganized than $\mathrm{K} 1$ (absence of bands at 3695, 3668, 3651 and 3620 $\mathrm{cm}^{-1}$ ). From the previous measurements, we have shown that the enthalpy of dehydration of a kaolinite increases with its degree of crystallinity. This result is confirmed by Koffi et al. [15] who showed that at $700^{\circ} \mathrm{C}$, the most crystalline kaolin yields a $64 \%$ dehydroxylated metakaolin and partially amorphous while the less crystallized kaolin leads to a $88 \%$ dehydroxylated metakaolin and totally amorphous.

If certain disadvantages (use of hydrofluoric acid for example) would tend to neglect this method, which until then was little used to determine the state of disorganization of metakaolins, there are many advantages that it possesses. It is very reliable and much faster than conventional methods of studying the hydraulicity of pozzolanic materials.

\section{References}

[1] Mitrović, A., Đuričić, R., Ilić, B. and Živanović, B. (2005) Metakaolin: Nova generacija dopunskih cementnih materijala. Materijali i konstrukcije, 48, 48-54.

[2] Siddique, R. and Klaus, J. (2009) Influence of Metakaolin on the Properties of Mortar and Concrete: A Review. Applied Clay Science, 43, 392-400. https://doi.org/10.1016/j.clay.2008.11.007

[3] Mitrović, A., Miličić, L. and Ilić, B. (2010) Benefits of Use Metakaolin in Cement-Based Systems. Treći internacionalni naučno-stručni skup Građevinarstvonauka i praksa, Zbornik radova, Žabljak, 15-19, 753-757.

[4] Ilic, B.R., Mitrovic, A.A. and Milicic, L.R. (2010) Thermal Treatment of Kaolin Clay to Obtain Metakaolin. Hemijska industrija, 64, 351-356. https://doi.org/10.2298/HEMIND100322014I

[5] Edomwonyi-Otu, L.C., Aderemi, B.O., Ahmed, A.S., Coville, N.J. and Maaza, M. (2013) Influence of Thermal Treatment on Kankara Kaolinite. Opticon, 15, 1-5.

[6] Lemaitre, J., Leonard, A.J. and Delmon, B. (1982) Le mécanisme de la transformation thermique de la métakaolinite. The Bull of Min, 105, 501-507.

[7] Murat, M., Amokrane, A.J., Bastide, P. and Montanaro, L. (1992) Synthesis of Zeolites from Thermally Activated Kaolinite. Some Observations on Nucleation and Growth. Clay Minerals, 27, 119-130. https://doi.org/10.1180/claymin.1992.027.1.12

[8] Frost, R.L. and Vassallo, A.M. (1996) The Dehydroxylation of the Kaolinite Clay Minerals Using Infrared Emission Spectroscopy. Clays and Clay Minerals, 44, 635-651. https://doi.org/10.1346/CCMN.1996.0440506

[9] Murat, M. and Driouche, M. (1988) Chemical Reactivity of Thermally Activated Clay Minerals. Cement and Concrete Research, 18, 221-228. https://doi.org/10.1016/0008-8846(88)90006-3

[10] Murat, M., Arnaud, Y., El Moussaouiti, M. and Comel, C. (1984) Détermination des 
teneurs en alumino-silicates cristallisées et amorphes dans les cendres volantes et les mullites synthétiques. Silicates Industriels, 53, 127-135.

[11] Mathurin, D., Chbihi, M.El.M. and Murat, M. (1987) Enthalpie de dissolution de différentes kaolinites et métakaolinites dans l'acide fluorhydrique. Influence des caractéristiques cristallochimique. Thermochimica Acta, 122, 79-85.

https://doi.org/10.1016/0040-6031(87)80107-7

[12] Mathurin, D., Chbihi, M.El.M. and Murat, M. (1986) Analyse de l'état d'amorphisation de la métakaolinite. Etude par calorimétrie de dissolution. Thermochimica Acta, 98, 49-55. https://doi.org/10.1016/0040-6031(86)87073-3

[13] Karym, H., Chbihi, M.El.M., Benmokhtar, S., Belaaouad, S. and Moutaabbid, M. (2015) Caracterisation of the Kaolinite Clay Minerals (Nador-North Morocco) Using Infrared Spectroscopy and Calorimetry of Dissolution. International Journal of Recent Scientific Research, 6, 4444-4448.

[14] Russel, J.D. (1987) Infrared Spectroscopy of Inorganic Compounds, Laboratory Methods in Infrared Spectroscopy. Wiley, New York.

[15] Konan, K.L., Soro, J., Andji, J.Y.Y., Oyetola, S. and Gabrielle Kra, J. (2010) Etude comparative de la déshydroxylation/amorphisation dans deux kaolins de cristallinité différente. Journal de la Société Ouest-Africaine de Chimie, 30, 29-39. 